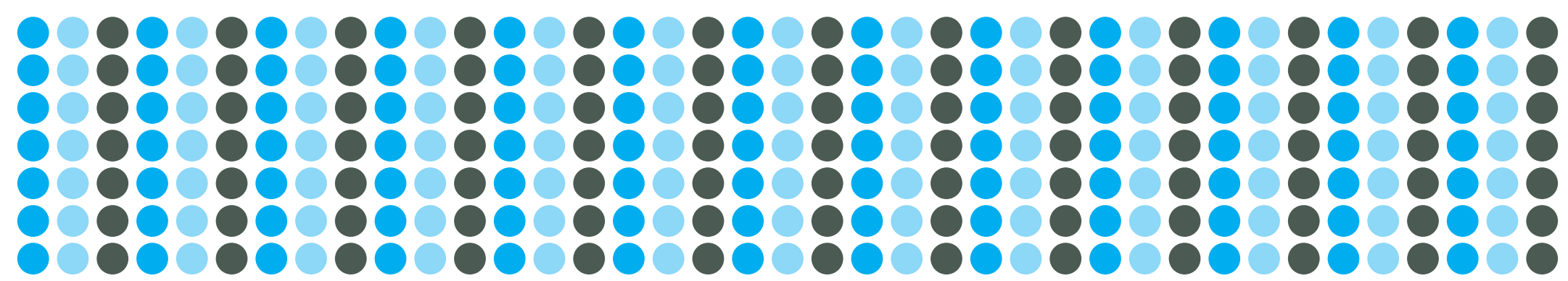

AUTHOR BIOGRAPHIES
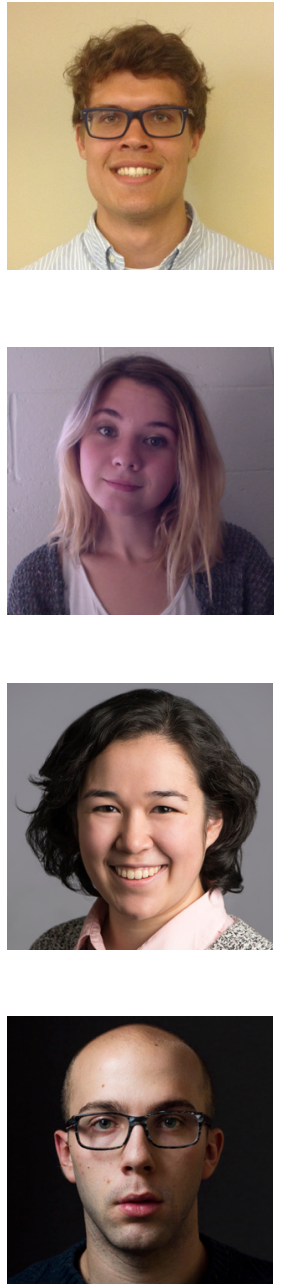

MAX BLAISDELL

Max graduated in the spring of 2016 and is now working in San Francisco as a paralegal for Leiff Cabraser Heimann \& Bernstein. He graduated cum laude with a major in International Studies and minors in Math and Political Science. Max worked as an undergraduate research assistant at the Boisi Center for Religion and American Public Life while at Boston College. His interests include comparative democratic transitions, the political philosophy of liberalism, and issues with integration in Europe. Max plans to continue his studies in graduate school and go on to pursue a career in academia.

\title{
VIOLET CASWELL
}

Violet is a senior at Boston College majoring in History and minoring in Theology and international studies. She is interested in religious history, faith elements in conflict, and public history. Currently, she is working on a Scholar of the College thesis about Dighton Rock, a forgotten piece of her hometown's history. After graduation, she hopes to attend graduate school and pursue a career in archival studies. She would like to thank the wonderful Dr. Virginia Reinburg for encouraging her to publish in Elements.

\section{LINDSEY CHOU}

Lindsey is a member of the Boston College Class of 2017. She is a lifelong resident of Massachusetts, where she lives with her parents and brother. She is currently pursuing a Bachelor's degree in Applied Psychology \& Human Development, with minors in English and Women's and Gender Studies. Having attended a Catholic high school, followed by a Catholic university, the intersections of religion and feminism are of significant academic and personal interest to her, as depicted in her essay in this journal.

\section{BENJAMIN FLYTHE}

Benjamin is a fine art photographer and freelance graphic designer living and working in Boston, MA. Having graduated from Boston College in 2016 with a degree in Art History, Ben's fields of study include fin-de-siècle Europe_-particularly Symbolism and Art Nouveau — as well as pop art and the Dutch Baroque. His personal art draws heavily from the theatricality of this last artistic era and his portraits have been compared to those of Rembrandt, especially with respect to the quality of his light and the emotion present in his sitters. While Ben hopes to be able to exhibit work both in Boston and elsewhere, he continues to develop his passion for art as an intern at the Abigail Ogilvy Gallery in Boston's SoWa district. 

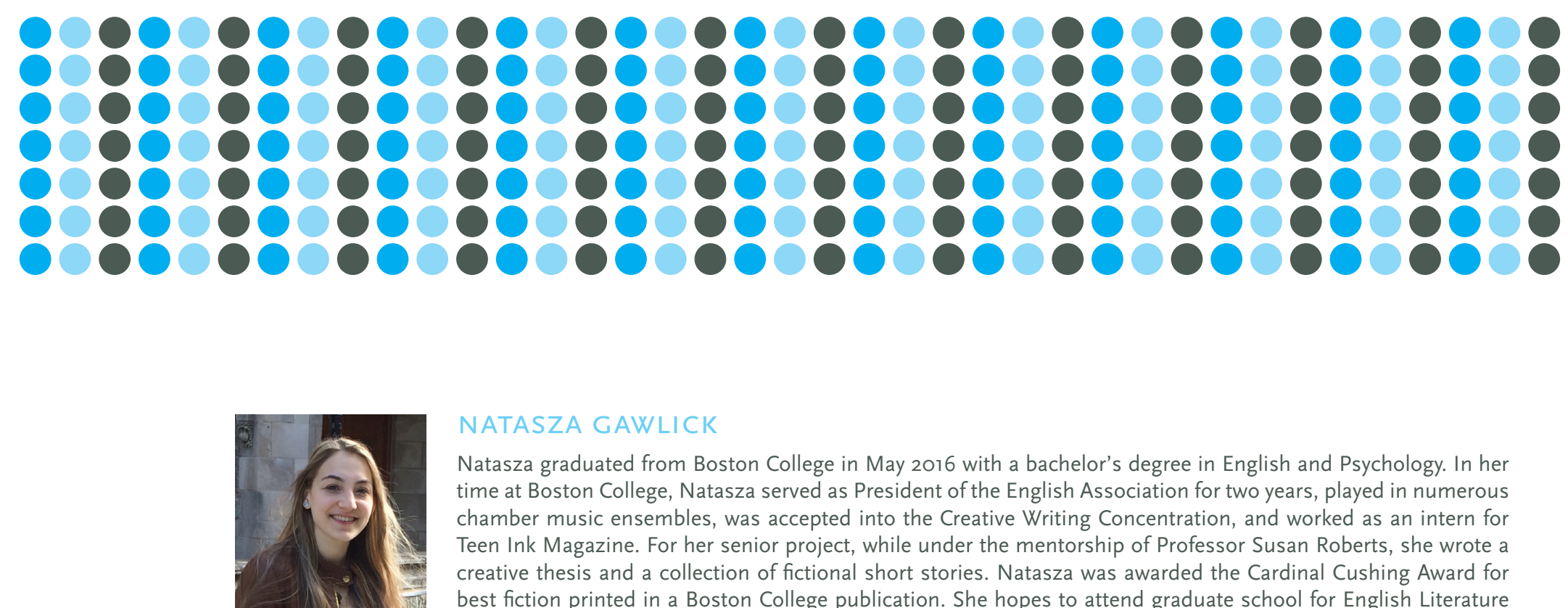

NATASZA GAWLICK

Natasza graduated from Boston College in May 2016 with a bachelor's degree in English and Psychology. In her time at Boston College, Natasza served as President of the English Association for two years, played in numerous chamber music ensembles, was accepted into the Creative Writing Concentration, and worked as an intern for Teen Ink Magazine. For her senior project, while under the mentorship of Professor Susan Roberts, she wrote a creative thesis and a collection of fictional short stories. Natasza was awarded the Cardinal Cushing Award for best fiction printed in a Boston College publication. She hopes to attend graduate school for English Literature and Creative Writing in the fall of 2017.

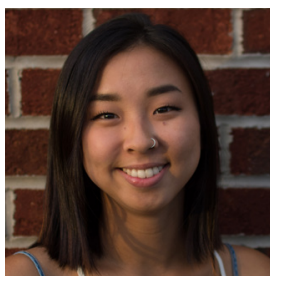

\section{CLARE KIM}

Clare is a junior in the Morrissey College of Arts and Sciences majoring in Communication and minoring in American Studies, with a concentration on Race and Ethnicity. She discovered her passion for social justice, especially with issues regarding race, after taking the introductory course to American Studies with Professor Lori Harrison-Kahan. Since then, Clare has joined the council for FACES, an organization that seeks to educate the BC community on issues of race through dialogue. On campus, she is the publicity director of WZBC, Boston College's student-run radio station, and works at Media Technology Services in the photography and graphics departments. Aside from academics, Clare enjoys art and hopes to pursue a career in the creative field.

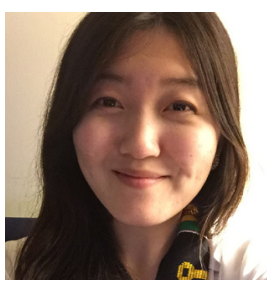

SOYEON KIM

Soyeon graduated from the Morrissey College of Arts and Sciences in 2016 with a Bachelor of Arts in Communication and a minor in African and African Diaspora Studies. After witnessing a case of police brutality and volunteering with underprivileged communities, she concentrated her studies on issues of social justice, especially those related to racism. Soyeon's research has been focused on the rhetoric of race in law and media studies, and she was a co-facilitator for Dialogues on Race at Boston College. This fall, she will be serving as an urban education fellow at Great Oaks Charter School in Newark, NJ for a year before pursuing a graduate degree in social work.

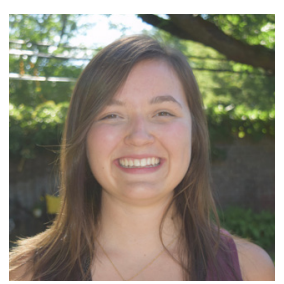

\section{MADELINE LEDDY}

Madeline is a junior in the Morrissey College of Arts and Sciences majoring in English with a minor in International Studies. Her academic interests include Gothic literature, twentieth-century literature, and war and conflict in the twentieth-century. On campus, she has worked as an Undergraduate Research Fellow in the Irish Studies department, as well as a moderator for Boston College's Lean In chapter and is a member of the University Chorale of Boston College. She is a native of Cleveland, Ohio and is very pleased with the results of the 2016 NBA Finals; however, she is spending her junior year abroad in the UK studying English and History at Mansfield College, Oxford University. 

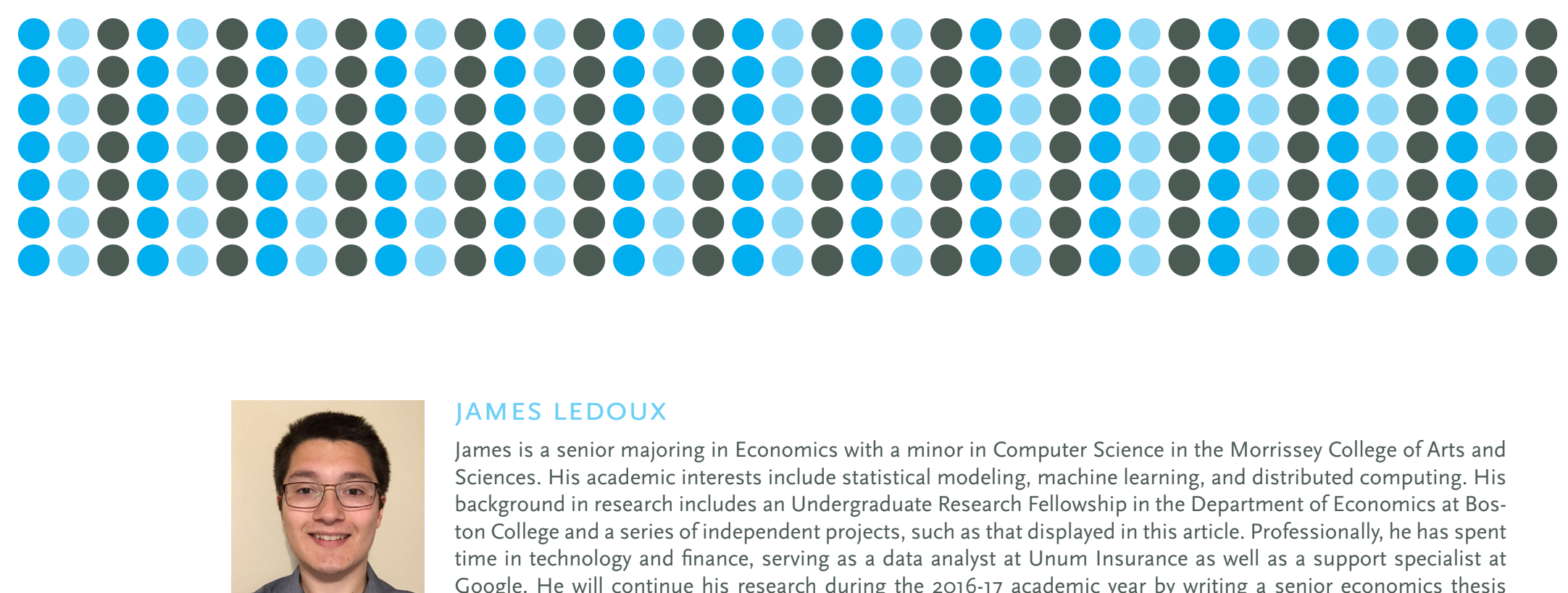

\section{JAMES LEDOUX}

James is a senior majoring in Economics with a minor in Computer Science in the Morrissey College of Arts and Sciences. His academic interests include statistical modeling, machine learning, and distributed computing. His background in research includes an Undergraduate Research Fellowship in the Department of Economics at Boston College and a series of independent projects, such as that displayed in this article. Professionally, he has spent time in technology and finance, serving as a data analyst at Unum Insurance as well as a support specialist at Google. He will continue his research during the 2016-17 academic year by writing a senior economics thesis under the guidance of Professor Chris Maxwell.

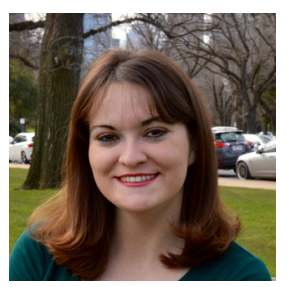

\section{SARAH SULLIVAN}

Sarah is a junior in the Morrissey College of Arts and Sciences double majoring in History and Psychology. She hopes to utilize and combine her knowledge in both areas for a potential career in the field of law. She is spending her Fall semester abroad at the University of Melbourne in Australia. In her spare time, Sarah enjoys writing for The Rock at Boston College, visiting art museums, and petting dogs. 